\title{
Money, Credit and Velocity
}

\section{MACK OTT}

Shakespeare: "Neither bortower, nor a lender be" (Hamlet, 1, in, 75, Polonius to Laertes)

Goethe: "Ifet us he in as small a circleas we will, we are either debtors or creditors before we have had fine to look around." (Elective Affinities, Bk. I, Ch. 4)

$\mathbf{R}$ and LNI many critics of monetary policy, and some monetary policymakers as well, have asserted that the links between monetary aggregates and national economic policy variables-that is, GNP, inflation and real economic growth-have been severed by a host of financial and credit manket unovations. If these critics are correct, then a monetary policy based on targeting the growth of a monetary aggregate would become increasingly inefective and inappropriate, as credit arrangements are substituted for monetary payments. ${ }^{1}$

The purpose of this article is to provide a theoretical framework in which to assess these clams

The author, an associate protessor of economics at The Pennsylvania State University, is a visiting scholar at the Federal Reserve Bank of St. Lomis.

1For examples, see Neil G. Berkman, "Abindoning Monetary Agrregates" in Controlling Monetary Aggregates 111 , pooceedings of a conference sponsored by the Federal Reserve Bank of Boston (October 1980), pp. 76-100; Beyamin M. Friedmu,

"The Relative Stability of Money and Credit "Velocities" in the United States: Fvidence and Some Speculations" NBER Working Paper No. 645 (March 1981); Anthomy M. Solomon, "Financial Innovation and Monetary Policy" (remarks before the foint Luncheon of the American Fonomic and American Finance Associations, December 28, 1981 ); James M. Tobin, "Inflation," in Encuctopedia of Economics, Douglats Greenwald, ed. (MeGraw-Hill, 1982), pD. 510-23. for the contrury position-i.e., that monetan policy should be undertaken thromgh effective control of a monetary aggregate-see Milon Friedman, "Mone tary Policy: "Theory and Practice." Jom of Woney, Credit and Banking (February 1982), pp. 98-118: and Alan N. Meltzer, Rober H. Rasche, Stephen H. Axilrod, and Peter Stermbigh, "Noney, Credit, and Banking Debate: Is the Federal Reserve's Monetary Control Policy Misdirected?" Joumal of Money. Credit and banking (Fenuary 1982), pp. 119-47. and to examine empirical evidence bearing on their puported policy consequences. The analysis prem sented in this article does not support the critics' assertions. This conclusion rests on two arguments. First, the relation between money and credit requires that the amount of credit granted match the anticipated amount of money that will be available to settle the debt when it comes due. Thus, regulating the rate of monetary growth, which in turn regulates the anticipated future quantity of money, determines the amount of credit and the conditions under which it is granted. This constraining influence of monetary growth on credit would be undone only if the relation between money and income growth departed from its historical pattem.

That it has not is the second argument: the empirical evidence on velocity, the relation between money growth and income growth, reveals no significant change during the last two years from its previous history. Consequently, despite recent claims to the contrary, the growth of the monetary aggregates is still reliably linked to the economic variables of interest to policymakers.

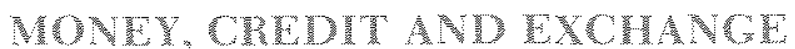

In contemporary soeieties, the exchange of goods is indirect. The purchase or sale of goods, whether in organized markets or through informal arrangements, is almost always in exchange for money or money-denominated promises. Direct bartering of one good for another is either nonexistent or unimportant.

The reason for this is at once obvious, yet theoretically challenging to elucidate. In the introduction to his book, The Theory of Money, Jurg Niehans observes:

Economists (and laymen) have always felt that the use of a medium of exhange increases the efficiency 
of an economy, The gain was usualy considered to be large. It has both qualitative and quantitive aspects. The qualitative aspects appear when monetary exchange is compared with barter. Classical and neoclassical economists were graphic in describing the "double coincidence of wants" of the hungry tailor and the shivering baker which would be necessary for an exchange in a barter economy and the narrow linitations it imposes on the division of labor. The use of money would increase welfare by freeing exchange from the shackles of the double coincidence of wants. ${ }^{2}$

Robert Clower succinctly summarized the results of these advantages as imposing a constraint on the exchange process: "Money buys goods and goods buy money; but goods do not buy goods." In other words, it is the nature of a system of monetary exchange to replace the cumbersome barter exchange of goods with two non-synchronized monetized exchanges: a sale of goods for money and a later purchase of goods by money. This exchange attribute in turn has implications for both the appropriate definition of money and for the monetary arrangements used in exchange. ${ }^{4}$

First, the period between the sale of one good for money and the subsequent purchase of another good may be long enough or predictable enough to allow the interim holding of funds in a non-transaction account. This implies that the appropriate monetary aggregate may not be narrowly defined money (i.e., M1), but a broader aggregate (e.g., M2) which con-

Jurg Niehuns, The Theron of Money (johns Hopkens University Press, 1978 , p. 2.

Bobert W. Clower, "A Reconsiderition of the Microfoundations of Monetary Theory, Western Economic Joumal (March 1967), 1. 6. Also, see Karl Brunner" and Allan H. Melter, "The Uses of Money: Money in the Theory of An Exchange Eeonomy," Americun Eromomic Revien (December 1971), pp. 784-805.

* Milton Friedman and Anna Schwartz described this attribute ats "the separation of the act of purchase from the act of sale," but criticized the medium of exchange approach as being too maxow to capture the essential nature of money:

In orker for the act of purchase to be sepatated from the act of sale, there must inded be something that will be generally accepted in payment-mthis is the feature emphasized in the "medium of exchange" approach. Butalso there must be something that can serve as a temporary abode of purchasing power, in which the seller holds the proceeds in the interim between sale and subseguent purchase or from which the buyer can extract the general purchasing power with which he pays for what he bays... Both features are necessary to permit the act of purchase to be separated from the act of sale, but the "something' that is generally accegted in payment need not contede with the "something' that serves as a temporary abode of purchasing power; the latter may include the fomer and more besides.

Milon Friedman and Anna Schwartz, Monetany Statistics of the United States: Estimates, Sontres, Methods (NBER, 1970), pp. 10607 . tains what Milton Friedman characterizes as "temporary abodes of purchasing power" that are readily convertible at low cost into an exchange medium..$^{5}$

Second, if the purchase of the good to be financed by the proceeds from the sale of another good pre. cedes the sale of that other good, then the anticipated future sale proceeds may be used to mediate the eartier purchase. Of course, an exchange arrangement like this is a familiar part of modem cconomies; such purchases are said to be made "on credit." Credit is granted by sellers or other third party lenders to buyers precisely on the basis of the buyer's anticipated future receipts (with the lender concurring) and, of course, is measured in monetary units. As a consequence, credit is as much of a medium of exchange as is money. ${ }^{6}$

While both credit and money are used to mediate exchange, they are obviously different entities. The quantity of money circulating in an economy is a stock; its units are used repeatedly in a sequence of exchanges. Credit, on the other hand, is a flow and is transaction-specific; it can only mediate the transaction for which it was created. ${ }^{7}$

5" wo goods that are perfect substitutes are economically the same good. If two durable goods are costlessly transformable, one into the other, then they are perfect substitutes in an inventory. On this criterion, if the cost of tansferring funds from a sivings account to a demane account or to curency were zero, then, dearly, savings accounts would be economically indistinguishable from demand accounts or curency and would be exchange media. Conversely, if the costs of trinsfer were probibitively large, satvings accounts would not be a close substitute for demand deposits. Hence, as Fredman and Schwaty argue, the question of what money is eamot be settled on an a priofi basis. but is an empircal guestion which, in part, depends on how costly inter-deposit transfers are.

eThes observation has led Clower and others to argue that some measure of cred at andabilit or line of credt be included in the policy relevant concept of money: " . . for most practical purposes, "money" should be considered to include trate credit as well as currency and denand deposits." Robert W. Clower. "Theoretical Founditions of Monetary Policy," in Monctary Theory and Monetan Policy in the 1970s, George Clayton, John C. Gilbert and Robert Sedgwick, eds. (Oxford University Press. 1971), p. 18. See also Athur B. Laffer, "Twade Credit and the Money Market" Warch 1970, pp, 239-67; and). Stephen Ferris, "A Transations Theory of Trade Credit Use," Quarterly Journal of Leonomics (May 1981), pp. 243-70.

Jt has been argued that credit is not an exchange medium, bat merely an arrangenent that rases the velocity of money fronically, the same argument was once used against including flemand deposits in money. As Friednan and Schwartz point out, mud of the 19 th century debate between the binking and currency schools entered on whether bank notes and deposits were money or merely "weans of raising the velocity of bank vatul cash but not als atding to the quanty of money." Friedman and Schwart, Monetary Statistics of the United States, p. 95. 


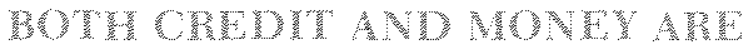

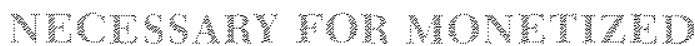 In}

The epigraphs from Shakespeare and Goethe represent conflicting views on the desirability and inevitability of credit; to wit, while money and credit are altemative exchange media, would either be sufficient to mediate all exchanges without the other? Could any of us, as Polonius suggests, avoid credit transactions completely? Conversely, could credit function as we know it without a monetary framework? Not surprisingly, the answer to both questions is no. Hence, the advice of Polonius is as fatuous as the character offering it. Both credit and money are necessary in the exchange process, each fulfilling functions that the other could not.

In order to establish this complementarity of money and credit, consider the exchange process as a contractual arrangement between buyer and seller. ${ }^{8}$ Under this characterization, the exchange and the settlement of the contract need not coincide in time so that either credit or money can mediate an exchange. In the case of a credit transaction, at the time of the exchange the buver incurs a contractual liability for a subsequent settlement to clear his debt. Using this contractual approach, we can now demonstrate why Goethe's claim of the inevitability of credit in any society is correct.

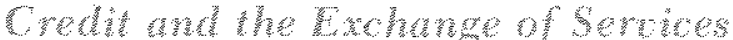

Two types of goods are voluntarily offered for exchange in markets: commodities and services. By definition, a commodity is a tangible physical entity not intrinsically dependent on time (e.g., an apple, a phonograph record or an automobile), while a service is an activity or process that is intangible and intrinsically sensible only with the passage of time (e.g., a gardener's chores, a concert or a taxi ride). In az monetized economy, sellers of either type of good

Buder Anglo-American law, am enforceable contract must have three elements:

(1) There must be an offer;

(2) There must be an acceptance precisely matching the offerelse it is at counter-offer;

(3) There nust be consideration-i.te, the offerom or acceptor mast make same performance that would be a detriment to him in the agreement were not inlfilled.

See "Contrat" and other veferenced citations thereunder in Henry Camplell Black, Black's Late Dictonem, 5th ed. (West Publishing Co, 1979), pp. 291-94,277. receive money or a promise to deliver money at a specified future time.

If only commodities were exchanged, it would be possible always to use money alone and never incur a debt. Services, however, by their very nature, cannot be exchanged without one party, either seller or buyer, extending credit to the other. Hence, a law attempting to enforce Shakespeare's admonition would not prohibit the sale of apples, automobiles or clothing; it would, however, prohibit the renting of a house, the purchase of a skimift ticket or the hiring of labor. In each of these latter examples, the transaction entails the exchange of money before or after the completion of the activity with, necessarily, a concomitant issuance of credit. ${ }^{9}$

Thus, Goethe was right: each of us inevitably engages in credit transactions every day. For example, we extend credit to our employer and receive it from our electric utility. If services of any form are to be exchanged, credit must be offered either by the seller-as in the typical employment arrangement where wages are received after the services have been delivered - or by the buyer-as in entertainment activities where the purchase of a ticket precedes the concert, game or movie. ${ }^{10}$

Clearly, credit is inextricably bound up with selling services in a monetized economy in order to avoid the problem of making an indefinitely large number of infinitesimal cash payments. Yet money and credit are simply altemative means of lowering the cost of exchanging goods relative to a primitive batter system. Thus, even some commodities might be too costly to exchange in customary ways if credit were ruled out (e.g., home-delivered newspapers or raw materials purchased by firms), ${ }^{11}$

\footnotetext{
Note that this would also rute out the existence of any firm other than owner-operated producers of eommodities.

iobarter exchange of services is concenvable as suggested in the maxim, "You scratch my back and [']l scratch yours." Yet, even here, credit sneaks in unless the exchange is simultaneous.

"Credit extended by sellers of raw materials is an especially importint example. If credis were not extended to producers. either deliveries would have to be made more frequenty (in smaller lots to mateh prodacers ash thow from sales of output. or the material-nsing fims would have to tie up more of their capital in raw material inventories and hence, less in the calpital to process these materials. Alternatively, firms would find it more ad yantageous to be vertically integrated-i,e, to own their suppliess-man to acruire these materials from other frms. See "Credit Allocation: An Fxercise an the Putility of Controls" (Citbank Economics Dept., 1979), p. 40. In any case-nore frequent delivery, larger inventories in capital, or more vertical integration-resoures would be less pooductively allocated than when credit is extended.
} 


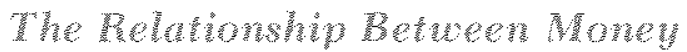 and Crodit}

Money and credit are both substitutes and complements in the exchange process. On the individual level, money and credit are potential substitutes for mediating any exchange of commodities. On the societal level, money and credit are complements in the exchange process; each provides a function necessary to some exchanges that the other cannot fulfill. In fact, credit is a more general medium of exchange than money in that it facilitates exchange involving time--both in permitting the sale of services and in pemitting differing delivery dates in exchanges of commodities; money withont credit can act as the exchange medium only for a commodity. Yet, money is likewise crucial to the functioning of credit through its role as the primary means of settlement.

Monetary theorists generally have agreed that money in modem economies is any thing that fulfills all of the following functions:
1. Medium of exchange,
2. Store of value,
3. Unit of account,
4. Standard of deferred payment.

Most economists have argued that the crucial characteristic in this list is its functioning as a medium of exchange. Typically, they have argued that any durable good can fulfill the remaining three functions, but only money can fulfill the first.

However, we have seen that credit also fulfills the medium of exchange function. Credit in our discussion has taken a special form-namely, credit measured in units of money and, implicitly, with the deferred payment to be made in units of money. In exchange systems with money and credit acting as exchange media, the other three functions in money's repertoire take on an importance not apparent in the conceptual monetary exchange models without credit.

Without agreement on the unit of account, credit transactions would have all the disadvantages of barter except simultaneity. Anthropologists, in contrast to economists, have placed more emphasis on the unit of account function because their focus is on how a monetized exchange system evolves from a barter system rather than how an extant monetized exchange system functions. ${ }^{12}$ From this vantage, they have documented that, in moving from batter to indirect exchange, the most useful function of primitive monies is the commonly-agreed-upon valuation unit. ${ }^{13}$

Finally, credit mediation of exchange is facilitated by the universal acceptability of money as a means of settlement - the standard of deferred payment function. All credit contracts can be settled (directly or through civil courts) by means of a money payment; that is, money is legal tender in our economy. This general agreement on the means of settlement makes credit less costly to extend, thereby increasing its avallability for exchange mediation. A decentralized use of credit requires that individuals and firms be able to clear their debts individually (i.e., pairwise) with some mutually agreeable means of settlement; without such agreement on the means of settlement, credit clearing would require a costly centralized system of record-keeping much like a "barter club."

\section{THE WELTWON OF CWEDT EXPANSON TO MONETARY POECH}

Credit is not money, but the promise of future money to the lender in retum for the temporary use of current purchasing power-goods or moneyextended to the borrower. Two errors that violate this logic occur every day in the financial press:

\footnotetext{
"2See Philip Grierson, "The Origins of Money" Research in Economit Anthropologw, Vol. I (JAI Press, Inc, 1978), especally pp. $9-12$ for evideuce on the impontance of standard of value in explaning early monetary systems. See also George Dalton, "Primitive Money," Ametican Anthropologist (1965. I), pp. 44-65; and Denise Schmandt-Bessemt, "The Entiest Precursors of Writing," Scientific American (June 1978), pp.50-59.

${ }^{13}$ In this context, it is ironic and revealing that contemporary "barten clubs nse dollars as the unt of account but not as an exchange medinm, Consider these descriptions from "As Barter Boom Keeps Growing," U.S. Neus and World Report Sep tember 21,1981 ), p. 58 :

A participant lists items for sale, and they are advertised to the other members. If a listed item is sold, the fomer owner is issued tride credits-sonetimes called trade dollass. These credits an later be used to purchase goods and services from other members.. "We don't make outright trades; we perform a banking function. . ."

This is also the method by which every "barter exchuge" profiled in the article appears to be organized:

Besides credits, most barter exchanges issue bater cards that can be ased for purchases at participating merchonts. Through the Trade Bank International exchange, a Memphis dentist hegan receiving customers who used their bater cards for dental work. Within a year's time, the dentist accunulated enongh trade dollars to buy carpeting for his offee, install new signs and yay for tying lessons.
} 
1. Refering to the interest rate as the price of money;

2. Identidying avalable credit as money ${ }^{2.4}$

The first error is so commonplace that its repetition makes it seem valid; nonetheless, the interest rate is not the price but the rental rate for a dollar or, properly expressed, any other good. The price of a dollar is a dollar's worth of something-certainly more than a mere percentage of a dollar. No one would refer to the rental rate at Hertz as the price of a new Ford, or to the rent on a house as its purchase price, but the confusion of interest on credit with the price of money has become so common that the error no longer jangles our sensibilities. Yet the distincu tion is not only obvious but as important for money and credit as for owned and rented automobiles.

Similarly, the second error, referring to available credit as money, also escapes rebuke through frequent use. The anmual total of credit extensions is many times larger than the year-to-year increases in either $\mathrm{M} 1$ or $\mathrm{M} 2$, and, in recent years, has been larger than the stock of Ml. Considering the consumer sector (which accounts for over 60 percent of national income), a large share of credit extensions, almost two-thirds, are by institutions other than commercial banks and, therefore, do not entail monetary expansion. Considering only instalment consumer credit, about 40 percent of such credit is extended by non-depository institutions with about 20 percent being extended by retailers and gasoline companies. In these retail extensions, money affects the transaction only though the anticipated monetary settlement. ${ }^{15}$

These errors are substantive for they focas the public's evaluation of monetary policy on regulating the flow of credit instead of controlling the grow th of the stock of money. Controlling the rate of growth of the money stock in a predictable fashion enhances the predictability of the future availability of the means of settlement. This regularity of monetary expansion makes for better-informed, intertemporal dexision-making and, therefore, contributes to the stabilization of credit markets. When non-monetary shocks occur, the predictable availability of quantities of money in the system allows maket-

\footnotetext{
${ }^{14}$ Recent exemples are (1) "The price of money-the interest rate-reflects, therefore the interation of millions of particin pants in the credit mathet. ." Herry Kanfman, Washington Pest, September 23, 1981: $(2)^{2 A s}$ long as the Federal Reserve Board mantains its coment coarse. credit or money avalable to lend-will remain tight." Hary B. Guis, Christian Srience Honiof, September 21,1981 .

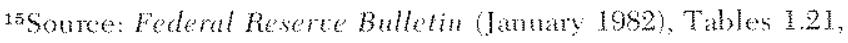
$1.56,1.57,1.58,2.16$
}

detemined signals-that is, interest rate changesto allocate credit efficiently to adjust to the shocks.

Conversely, attempting to control interest rates requires the monetary au thority, in effect, to allocate credit at the cost of making the growth rate of monetary expansion less predictable; since this makes the real future value of the means of settlement more variable, credit transactions become riskier, and credit markets less stable. When non-monetary shocks occur, the less predictable quantities of means of settlement with relatively fixed interest rates impede market signals from efficiently allom cating credit.

Since both money and credit are exchange media, the key to effectively controlling either or both of them must be first to isolate their interconnections and mutual dependencies. This article has argued that credit is unavoidable and that a money means of settlement is necessary for a decentralized credit system. What it now addresses is how monetary and creditexpansion relate to each other and how both of these relate to national income.

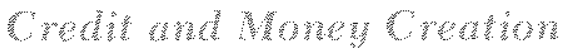

In contemporary market economies, the money supply grows through two types of credit transactions: the central bank creating deposits (money) and bank reserves by buying government securities, and depository institutions creating deposits (money) from increased reserves by granting loans. ${ }^{16}$

Of course, not all credit extensions entail monetary expansion. There are three distinct sources of credit extension: (1) bank and non-bank depository institutions (commercial banks, savings and loans, credit unions, matual savings banks); (2) nondepository financial intemediares (finance com-

\footnotetext{
16 In other words, modem monetary systems have a fiat baseliterally noney by decree-with depository hustitutions, acting as fiducties, creating olvigations aganst themselves with the fat base acting in part as reserves. The decree appears on the currency notes: "This note is tegal tender for all debts, publis and pritate:" While no individmal could refine to accept such money for debt repanent, exchure contrats cond tasily be composed ta thwat its the in everyay commere. However, a forceful explanation as to why money is acesped is that the fedequl govemnent requives it as pument for tax liabilities. Anticipation of the veed to dear this debt creates a demand for the pure fict dollar, gifarintering its exchange value. See Abba P. Lemer, "Noney as a Crenture of the State" Anerican Leonowle Retce May 1947 , pp $312-17$ and Ross $\mathrm{V}$. Statr, "The Price of Mones in is Pure Fachome Monetary Economs with Taxation," Econometrica Uamatry 1974, , 15.454.
} 
panies, investment banks, brokerages, insurance companies); and (3) sellers of goods (retail and trade credit). In the first case, a depository institution lends money to a bonower who in turn uses these funds to purchase goods or repay debts; the credit extension entails monetary expansion of purchasing power because it consists of checkable deposit expansion. During the last three decades, loans by such depository institutions have accounted for between 35 and 50 percent of the amnual total of credit market funds extended to the non-financial sector. ${ }^{17}$ Altematively put, more than half of the credit extended annually in U.S. financial makets does not entail deposit expansion.

In the second case, a non-depository institution (e.g., a consumer finance company) issues the credit or buys the accounts receivable of a credit-issuing seller. The latter method of credit extension is called factoring, and non-depository institutions fund this activity by either selling debentures directly or by acting as an agent for a depository institution. Under either method, the extension of credit does not entail an expansion of deposits but a reallocation of exist. ing deposit holdings. ${ }^{18}$

Finally, in case three, credit may be extended directly by the seller of goods and held as accounts receivable. Often this credit is financed by the sale of commercial paper issued by the seller/credit-issuer (e.g., firms with their own financial subsidiaries such as Sears or General Motors). In these instances, whether the firm holds its own accounts receivable, factors its accounts receivable or sells commercial paper, the extended credit represents an increase in purchasing power not created by checkable deposit expansion.

\footnotetext{
7 Source: Board al Governors, Federal Reserve System. Of course, this credit expansion is limited by bank reserves moler a given set of reserve requirements and is consecuently directly controlled by the monetary authority. For this form of credit, additional credit control authority would be superftuous. This case also covers bank credit card usage since credit issued by a seller to abuyer aganst a bank card becomes a demand deposit increment as soon as the selleveredit-issuer submits the credit invoice to the agent bank. In both types of ctedit extension, direct on credit card, a depository institution creates money matching the extended credit.

18If a clepository institution issues a loan to a creditor using the acconnts or debt as collateral, then the credit extension has the same one-for-one expansion of deposits as if the loan were directly placed. From 1977 through 1980, the percentage of installment loans by norr-depository institutions was .39 .37 , $.40, .45$ respectively; sontce: Federal Reserve Bulletin (September 1981), table 1.57. A breakdown for non-instaliment credit has not been present in the Bullefin since 1975 , but from 1965 to 1975, commercial banks extended only about one-third of single-payment non-installment loans.
}

In the second and third cases, credit extensions substitute for monetary mediation, while, in the first case, a dollar of money is created by each dollar of credit extended. Thus, for the case of loans by deposit creation, credit expansion has no apparent impact on the relation between the narrowly defined money supply and income since $M I$ and credit move together; however, in the latter two cases, credit substitutes for money which apparently would change the ratio of income to money supply.

Yet, to the extent that credit arrangements increasingly provide as ready a source of purchasing power as narrowly defined money (M1), the appearances of these cases are somewhat misleading. There should be an incentive to reduce $\mathrm{M} I$ holdings and to increase the non-M1 portion of M2 holdings. For example, given the rising acceptability of bank credit cards-about 30 percent of U.S. retail and service establishments accepted them in 1972, approximately 50 percent in 1981 - the utility of hold. ing a reserve of currency or demand deposit balances in order to mediate unforeseen or spur-of-the. moment purchases has been significantly reduced for consumers. ${ }^{19}$ Still, to clear the short-term credit card debt at month's end, a ready source of funds to shift to demand or other checkable deposits remains necessary. Consequently, even if the proportions of cash and credit purchases were constant, given the increasing acceptability of credit as an exchange nedium, it would not be surprising to see consumer holdings of demand deposits decline relative to purchases (i.e., to have had a rising velocity).

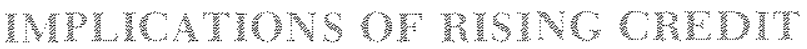

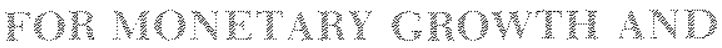

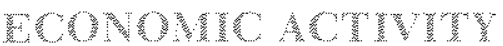

If all credit extensions represented monetary expansion, then controlling monetary growth would control credit. The same constraint that limiting reserves imposes on deposit expansion also limits

\footnotetext{
19The total number of merchant (i.e., retail and service) estab] ishments in the United States rose less than 2 percent per year during the $1960 \mathrm{~s}$ and $1970 \mathrm{~s}$, while the number of merchant outlets accepting MastezCard and VISA rose at over 8 percent and 9 percent per year, respectively. (Sources: Statistical Abstract of the United States, 1980 (0.S. Dept of Commerce, Bureat of the Census), 101 st ed., and data supplied by VISA and MasterCard). To estimate the percentage of merchants accepting bank cards, we estimated total merchats for 1981 by exw trapolating the 2 percent annual growth rate from 1977 forward. This was then divident into the number of merchant outlets that accept MasterCard.
} 
credit extensions, and inflation policy can properly focus on controlling money growth, leaving the market to allocate credit. As we have seen, however, depository institutions account for less than half of the credit annually extended in the United States. Consequently, might not the purchasing power created by non-deposit credit extensions render monetary policies undertaken through control of monetary growth rates ineffective? The answer is no: money in its role as the means of settlement constrains non-depository as well as depository credit.

If an increase in the use of credit alters the moneyincome relationship, the income velocity of money will rise. That is, if a larger share of transactions by households or fims can be mediated by credit, those households and firms, relative to their incomes, will plan to hold less MI and more of other assets, including non-M $\mathrm{l}$ deposits. As this substitution occurs, the ratio of nominal income to $\mathrm{MI}$ (velocity) will rise. Whether such a change will occur for all monetary aggregates, narrow and broad, depends on the extent to which substitutions of non-Ml assets for $\mathrm{Ml}$ comprise deposits included in other monetary aggregates. ${ }^{20}$

Velocity, $v$, which is the ratio of nominal gross national product, $\mathrm{Y}$, to money, $\mathrm{M}$,

$$
\mathrm{Y}=\frac{\mathrm{Y}}{\mathrm{M}}
$$

measures the turnover rate of the average dollar in $M$, that is, how many times a dollar was used in a transaction involving $\mathrm{Y}$ during the year. ${ }^{21}$ Expressing nominal income as the product of the price level, $P$, and real output, $y$,

$$
\mathrm{Y}=\mathrm{Py},
$$

we obtain an equation for the growth rate of velocity,

\footnotetext{
aressentialy, this is again Friedman's argument that the definition of money is not in a protoi but an empirical issue. "The selection [of money's definition] is to be regarded as an em pirical hyothesis asserting that a particalat definition will be most convenient for a particular purpose becuuse the magnitude based on that definition bears a more consistent and regular relation to other variables relevant for the parpose than do alternative magnitudes of the same general class.... It maty well be that the specific meaning it is most convenient to attach to the tem money differs for tifferent periods, under different institutional arrangements, or for different purposes." Friedman and Schwartz. Monetury Stafistics of the Unifed States, p. 91.

2.1The reciprocal of velocity measures the avenage bolding period of a dollar, how long between final income transactions. This period is gemane to the Friedman notion of temporary abode of purchasing power.
}

$$
\dot{v}=\dot{p}+\dot{y}-\dot{M},
$$

from equation 1 , where ${ }^{\cdot}$ indicates the annualized growth rate of each variable. From equation 3, we obtain

$$
\dot{\mathrm{P}}=\dot{\mathrm{v}}-\dot{\mathrm{y}}+\dot{\mathrm{M}}
$$

which shows the significance of velocity for monetary policy with the inflation rate, $\dot{\mathrm{P}}$, as its target.

As is obvious from equation 4 , if velocity is con$\operatorname{stant}(\mathrm{v}=0$ ), then the inflation rate will be equal to the difference between the growth rates of real output, $\dot{\mathrm{y}}$, and money, $\dot{\mathrm{M}}$; if $\dot{\mathrm{v}}$ is relatively constant but non-zero, then inflation would be the difference between the growth rates of money and real output plus that of velocity. If $\dot{v}$ does not depend on $\dot{M}$ or $\dot{y}$, then equation 4 implies that if $\dot{v}$ is simply pre dictable, even if not constant, then controlling the money supply is tantamount to controlling inflation. ${ }^{22}$

This interpretation abstracts from variations in real output, but, to the extent that fluctuations in the growth rate of money exacerbate such variations, setting a constant grow th rate of money reduces that source of disturbance. Non-monetary disturbances to real output growth (e.g., the OPEC oil embargo), of course, may cause inflation to deviate from its anticipated path, but over longer periods of time, a steady growth rate of money will smooth real income growth as well as facilitate infation predictability. This is the rationale for a policy of targeting on the growth rate of money and why its effectiveness depends upon the predictability of velocity. ${ }^{23}$

Assessing the predictability of a variable involves two separate evaluations: point forecasts and variability. The shorter the time period considered, the relatively more important is the latter characteristic; that is, while a short-run forecast of a variable nay rarely be precise, if that variable does not fluctuate wildly in a fashion out of keeping with its history, then describing it as predictable is sensible.

\footnotetext{
${ }^{22}$ Note that for policy pumposes we need not know precisely why the growth nite of velocity is predictable; for the pupose of formulating an infiation policy throngh control of a monetary aggregate, it is sufficient that it is predictable.

${ }^{23}$ For a more detailed statement, see Milton Friedman, "A Theoretical Franework for Monetary Analvsis," Joumal of Political Economy (March/April 1970), pp. 193-238. Fredman also argues that monetary policy is not useful in combter-cylical policy becanse of lags in its impacts and that, consecuently, it is more useful if steady or predictable; see his Americm Economic Association Presidential Address, "The Role of Monetary Polics," American Economic Reciew (Mard 1968), pp 1-17, and his "Monetary Policy" lecture cited in footnote 1.
} 


\section{Chort 1}

\section{Income, Money and Credit}

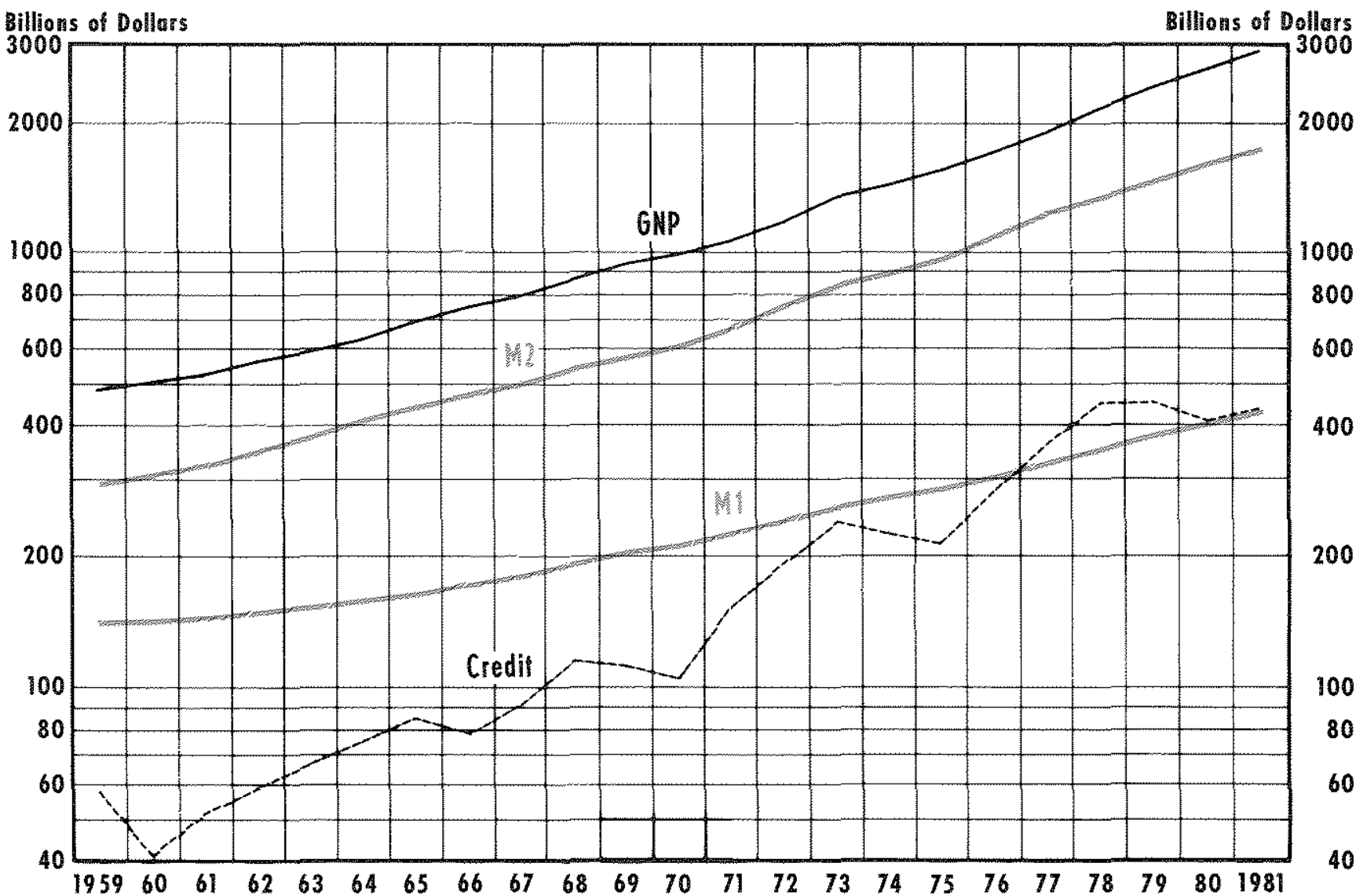

\section{羙AS A

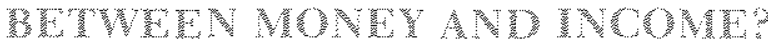

There are several ways to assess the impact of rising credit on the money-income link. Three different procedures are used here: (1) a consideration of the levels of GNP, money and credit; (2) an examination of consumer deposit holdings, credit extensions and purchases; (3) observations of the growth rates of $\mathrm{M} 1$ and $M 2$ velocities.

First, we can see whether the relationship between money and income growth appears to have changed in recent years by simply looking at the data on income, money and credit presented in chart 1. Chart 1 , using a semi-log scale, depicts ammal GNP, M1 and M2 holdings, and credit flows, with the last defined as the quantity of funds raised in credit markets by firms, consumes and the govemment, plus trade credit extended between firms. ${ }^{24}$ On a semi-log chart, constant growth rates graph as straight lines, and equal growth rates appear as parallel lines. In this fomat, it is plain that from 1959 to 1981 credit's growth was the fastest of the aggre. gates, that GNP and $M 2$ have grown at roughly equal rates, and that all thee grew somewhat faster than M1. The credit magnitude grew at an average rate of 9.2 percent per year, while M2 grew at about the same rate as GNP during the last two decades-8.3

\footnotetext{
24 Note that it is the fow of credit-i.e, fatensions-not the sock of debt that is relewan here. Credit, as discussed earlier is transation-specifie and an mediate on that trancaction for wheth it is extended. Fen if the promissory note from a plem vous credit transtetion were subsequently used chs collaterit for another credit transaction, thene would be another adit extension for that tansacton. Unlike past money expansion, the stock of past extensions is, in itsell irrelevat.
} 
Chart 2

Velocities of $M 1$ and $M 2$

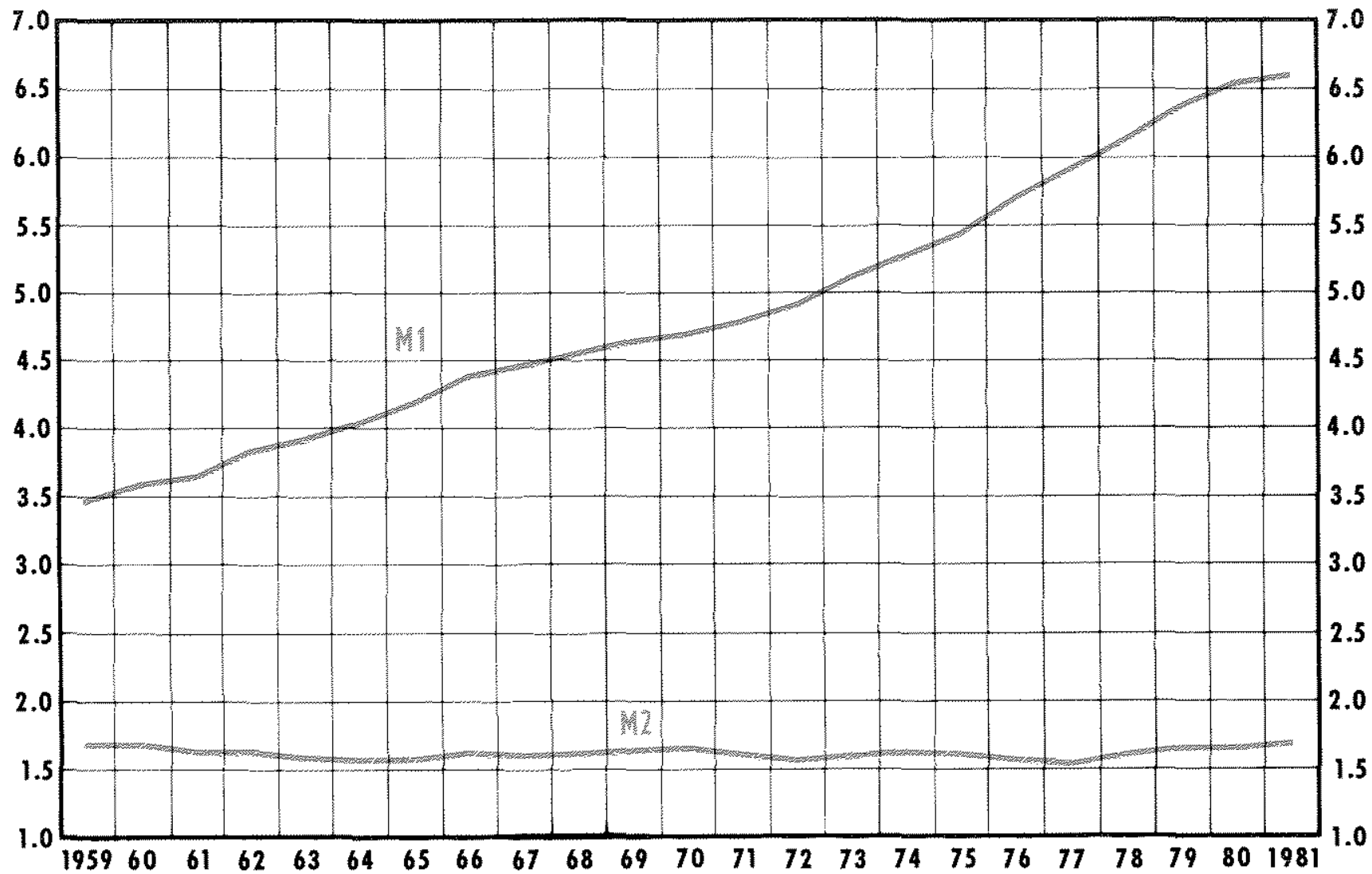

percent and 8.2 percent per year, respectively. In contrast, M1 grew at a 5.2 percent rate.

In chart 2 , the velocities of $\mathrm{M} 1$ and $\mathrm{M} 2$ are displayed. The approximate constancy of the $\mathrm{M} 2$ velocity is clearly evident here, as well as the persistent rise of Ml velocity. Not so evident, however, is the relatively constant rate of $M 1$ velocity growth. Over the 1959-81 period, $M 1$ velocity grew at around 3.2 percent. Indeed, except for a noticeable slowing in the late ' 60 s, the velocity growth rate of both old $\mathrm{MI}$ and new $\mathrm{M} 1$ has been between 3 percent and 4 percent since 1950.25

25Recently, Robert E. Weintrub senior ecomomint for the Joint Exononic Committe of the U.S. Congress, mitde at simila point in a letter to the Wall Stret Jommi, October 14, 1981: "As a matter of logic, of fhore and other new financhal developments fan contribute to inflation only if they contribute to the rate of rise of momey's velocty. However, they have not since the early $1950^{2}$, the nate or rise of MLB's velocity has been quite steidy, $3.2 \%$ yearly."
The ratio of credit to income, while persistently rising, probably understates the importance of credit in explaining the rise of $\mathrm{M} 1$ velocity. The credit total is misleadingly low since it represents quarterly balance sheet changes in debt. If credit is extended and repaid within the period of observation cone quarter for the data in chart 1 ), there is no change in the credit balance and, thus, no evidence that this credit extension took place; nonetheless, such extensions of credit would have mediated exchanges and contributed to spending and economic activity.

A second way to assess the impact of credit use is to focus on the behavior of individuals and familiesin particular, to examine their holdings of demand and other checkable deposits as compared to credit in mediating consumer purchases. Table 1 presents data on consumer deposit holdings, credit exten. sions and purchases in the U.S. economy during the 1970s. By focusing on the consumer sector, three 
Table 1

Consumer Deposits, Credit, Expenditures and Deposit Velocities (amounts in billions of dollars)

\begin{tabular}{|c|c|c|c|c|c|c|c|c|c|c|c|c|}
\hline \multirow[b]{2}{*}{ Year } & \multicolumn{5}{|c|}{ Consumer Deposits and Credit: } & \multicolumn{3}{|c|}{ Consumer Expenditures and Mediations } & \multicolumn{4}{|c|}{ Velocities } \\
\hline & $\begin{array}{l}\text { Demand } \\
\text { deposits }\end{array}$ & $\begin{array}{r}\text { (2) } \\
\text { Other } \\
\text { checkable } \\
\text { deposts }\end{array}$ & $\begin{array}{l}\text { (3) } \\
\text { Total } \\
\text { checkable } \\
\text { deposits }\end{array}$ & $\begin{array}{l}\text { Consumer Ma } \\
\text { deposits }\end{array}$ & $\begin{array}{l}\text { (5) } \\
\text { Total } \\
\text { consumer } \\
\text { credit } \\
\text { extensions }\end{array}$ & $\begin{array}{l}\text { (6) } \\
\text { Personal } \\
\text { consumption } \\
\text { expenditures }\end{array}$ & $\begin{array}{l}\text { (7) } \\
\text { Total } \\
\text { cast } \\
\text { purchases }\end{array}$ & $\begin{array}{l}\text { (8) } \\
\text { Percent } \\
\text { cash } \\
\text { purchases }\end{array}$ & $6 \div 1$ & $6 \div 3$ & $7+3$ & $6-4$ \\
\hline 1970 & $\$ 53,6$ & $\$ 04$ & $\$ 540$ & $\$ 4585$ & $\$ 187,1$ & $\$ 634.1$ & $\$ 447.0$ & $70.5 \%$ & 11,83 & 14.74 & 8.27 & 1,38 \\
\hline 1971 & 58.6 & 0.5 & 591 & 5323 & 2158 & 6926 & 476.8 & 68.8 & 11.82 & 11.72 & 8.07 & 130 \\
\hline 1972 & 654 & 0.6 & 660 & 6098 & 2408 & 7670 & 5262 & 68.6 & 11.73 & 11.62 & 797 & 126 \\
\hline 1973 & 70,1 & 08 & 70.9 & 6548 & 2690 & 8343 & 565.3 & 67.8 & 11,90 & 11.77 & 7.97 & 127 \\
\hline 1974 & 733 & 0.9 & 742 & 6944 & 269.4 & 9141 & 6447 & 70.5 & 12.47 & 12,32 & 869 & 132 \\
\hline 1975 & 780 & 16 & 796 & 7962 & 2807 & 10169 & 736.2 & 724 & 13.04 & 1278 & 925 & 128 \\
\hline 1976 & 826 & 32 & 858 & 9212 & 3182 & 11279 & 809.7 & 718 & 13.65 & 13,15 & 9,44 & 122 \\
\hline 1977 & 910 & 48 & 958 & 1034.8 & 3735 & 12545 & 881,0 & 702 & 13.79 & 13.09 & 820 & 121 \\
\hline 1978 & 974 & 78 & 1052 & 11175 & 4242 & 14166 & 9924 & 70.1 & 14.54 & 13.47 & 9,43 & 127 \\
\hline 1979 & 892 & 177 & 116.9 & 12001 & 465.8 & 15823 & $1+16.5$ & 70.6 & 15.95 & 13.54 & 955 & 132 \\
\hline 1980 & 1024 & 274 & 129.8 & 1286.2 & 4493 & 17510 & $\$ 3017$ & 7.43 & 17.10 & 13,49 & 1003 & 136 \\
\hline 1981 & 86.6 & 744 & 1610 & 14008 & 4772 & 1909.5 & 1432.3 & 74.1 & 2205 & 1186 & 890 & 136 \\
\hline $\begin{array}{r}\operatorname{tes}(1) \\
(2) \\
(3) \\
(4) \\
\end{array}$ & $\begin{array}{l}\text { GrossiPC } \\
\text { Federal } \\
\text { Now ano } \\
\text { deposits } \\
\text { IPC cons } \\
\text { M2 minu } \\
\text { money } \\
\text { posits pl } \\
\text { deposits }\end{array}$ & $\begin{array}{l}\text { Consumer } \\
\text { eserve Bullet } \\
\text { ATs accoun } \\
\text { tmutualsay } \\
\text { mer demand } \\
\text { overnight } \\
\text { arket mutual } \\
\text { sipc consun } \\
\text { Source Fed }\end{array}$ & $\begin{array}{l}\text { and deposit } \\
\text { Figure tor } \\
\text { oredit unior } \\
\text { sbanks sou } \\
\text { eposits plus } \\
\text { rodollars m } \\
\text { nds minus } c \\
\text { demand } \\
\text { I Reserve } B u\end{array}$ & $\begin{array}{l}\text { Is preliminary } \\
\text { hare drafts and } \\
\text { Federal Reserv } \\
\text { ier checkable d } \\
\text { s overnight } \mathrm{RP} \\
\text { ency minus den } \\
\text { its plis other ch } \\
\text { tin. }\end{array}$ & $\begin{array}{l}\text { ource } \\
\text { emand } \\
\text { Board } \\
\text { osits } \\
\text { minus } \\
\text { hd de } \\
\text { ckable }\end{array}$ & $\begin{array}{l}\text { (6) } \mathrm{Ex} \\
\text { (7) } \mathrm{Pe} \\
\text { (8) } \mathrm{Th}\end{array}$ & $\begin{array}{l}\text { umer nsta } \\
\text { uecemberto } \\
\text { times che } D \\
\text { th term-to- } \\
\text { age) source } \\
\text { essed at an } \\
\text { onal consun } \\
\text { (6) - Col ( } 5 \\
\text { ratio of tota }\end{array}$ & $\begin{array}{l}\text { ment credit } \\
\text { sutstanding } \\
\text { lfot that year } \\
\text { cember total } \\
\text { aturity struct } \\
\text { Federal Rest } \\
\text { fal rates sou } \\
\text { ption expend } \\
\text { cast purcha }\end{array}$ & $\begin{array}{l}\text { theinst } \\
\text { while th } \\
\text { (under } \\
\text { ire of } n \\
\text { rve Boa } \\
\text { rce: Dep } \\
\text { tures le } \\
\text { ies to } p e\end{array}$ & $\begin{array}{l}\text { is plus } \\
\text { Iment } \\
\text { non-in } \\
\text { he ass } \\
\text { oninsta } \\
\text { d. } \\
\text { artment } \\
\text { s total } \\
\text { rsonal. }\end{array}$ & $\begin{array}{l}\text { orins } \\
\text { alime is } \\
\text { aption } \\
\text { ment c } \\
\text { f Comn } \\
\text { onsume } \\
\cdots \\
\text { onsump }\end{array}$ & $\begin{array}{l}\text { almen } \\
\text { gures } \\
\text { fure six- } \\
\text { ait, on } \\
\text { erce } \\
\text { oredit } \\
\text { on ex }\end{array}$ \\
\hline
\end{tabular}


technical national income accounting and comparability problems are avoided. First, all personal consumption expenditures are final goods tansactions and appear in GNP; in fact, they are over 60 percent of this measure. Hence, all the credit extensions to consumers are used for final goods purchases. In comtrast, commercial credit and trade cedit may be finanche intemediate goods. Second, a direct comparison of credit use and demand deposit holdings for an identifiable set of buyers is made possible; hence, characterizations about the relative use of credit and demand deposits in relation to income are facilitated. Thind, data on credit extensions are available so that a truer picture of credit utilization can be obtained than when using balance sheet changes in debt.

The data in table 1 characterize the mamer in which households have made their purchases and held their deposits during the last 12 years; these data are based on fouth quarter and December observations in each year. Clearly evident is the recent substitution of non-bank checkable deposits for demand deposits (columns 1 and 2), as well as the steady decline in holdings of demand deposits relative to total purchases (column 6 ) measured by their velocity (column 9). Conversely, the ratio of purchases to total consumer checkable deposits, the velocity of total checkable deposits (column 10), rose much more gradually and fell abrupty in 1981 to about its level in 1970 .

As the data indicate, the proportions of consumer transactions initially mediated by money and credit (colum 6) varied only slightly during the 1970 ; the share of purchases that were medated by currency and demand deposits remained around 70 percent (assuming a six-month term to maturity in noninstallment credit) over the decade. Thus, over this period of rough constancy in the distribution of types of mediation, the ratio of consumer expenditures to demand deposit holdings by consumers (column 9) increased by almost 45 percent. Conversely, the ratio of purchases to total checkable deposits rose only 15 percent through 1980 (column 10). More over, in 1981, demand deposits tell abrupty (colum 1) and other checkable deposits rose even more sharply (column 2) after the institution of $\mathrm{NOW}$ accounts nationwide. As a result, the velocity of total checkables fell in 1981 to approximately its 1970 value.

If we assume a narrow or transactions mediam defunition of money, MI, the observations over 1970 80 would be evidence of a decline in the quantity of money demanded by households. On the other hand, if we consider total checkables in $1981 \mathrm{or}^{2}$ assume a broader temporary-abode-of-purchasingpower definition, $\mathbf{M}$, then the ratios of consumer expenditures to the comsumer deposit holdings prom vide contrary evidence. As shown in colmm 12 of the table, the ratio of consumer expenditures to the sum of household demand deposits, saving and small time deposits, and money market mutual funds varied comparatively little relative to the demand depost and total checkables ratios. Thus, under the broader definition, the quantity of money demanded -at least the consumer portion-does not appear to have declined during the 1970s. In particular, 1980 and 1981 do not appear to be qualitatively different than the earlier years.

The third manner of assessing credit's impact is to detemine whether the trends in the income velocities of the monetary aggregates have changed significantly in recent years. As we saw in the slopes of $M 1$ and $M 2$ velocities in chart 2 , monetary aggregate velocities had strong trends in their growth over the two decades 1959-81. While on a quater-toquarter basis velocity growth rates exhibit significant vanability, chat 2 suggests that over longer periods velocity growth is farly regular. This trend regularity is substantiated in chart 3 , which plots the growth rates of $\mathrm{Ml}$ and $\mathrm{M} 2$ velocities. In this chart, quater-to-quarter (QQ), four-quarter moving average (4QMA) and 20-quarter moving average (Trend) growth rates appear. While QQ is highly variable for both Ml and M2, the 4 QMA for each has a markedly smaller amplitude; considering \pm 4 percent bands, only one observation for Ml's velocity growth and three observations for M2's velocity growth lie beyond them. Also, the trend lor each strongly underscores the apparent tendencies in chart 2 ; in each case, MI and M2 velocities have stable trends, especially when measured over periods longer than a year. In particular, the charts do not reveal recent velocity growth to have been qualitatively different than in ealler years.

This lack of change in M $\mathrm{L}$ and M2 velocity growth is evert more apparent in table 2, which displays velocity growth rates, their standard deviations, and their ranges for $1961-81$, for fve-year subperiods, and for the year 1981; growth ates are computed for two observation frequencies: quater-to-guarter (QQ) and four-quarter moving average (4QMA).

Consider the behavior of $\mathrm{Ml}$ velocity computed on a quarterly basis. Over the entire $1961-81$ period, it has had an average growth rate of 3.16 percent per 


\section{Char 3}

Velocity Growth Rates
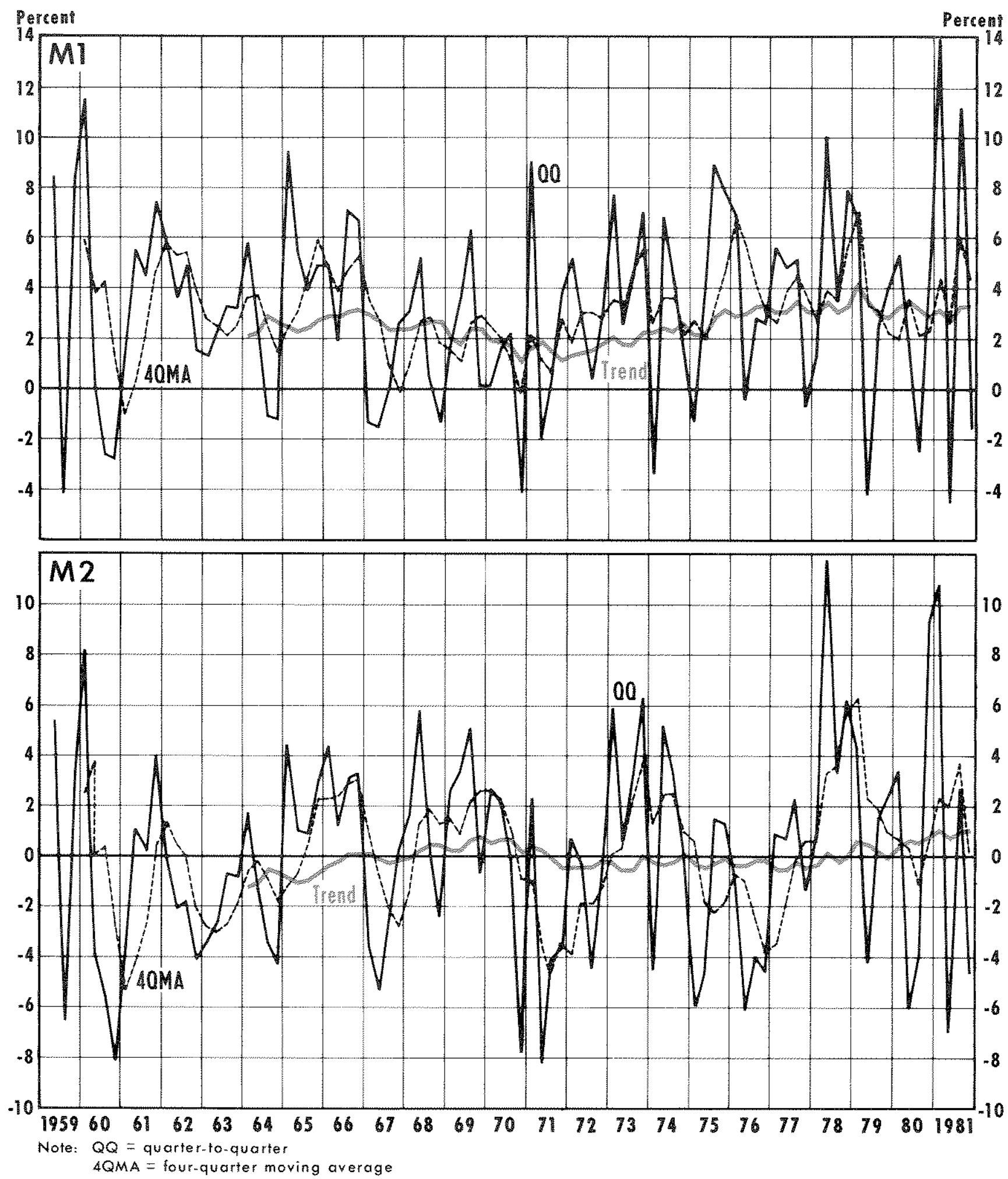
Table 2

Annual Growth Rates of M1 and M2 Velocities During 1961-81

\begin{tabular}{|c|c|c|c|c|c|c|c|c|}
\hline Aggregate & $\begin{array}{l}\text { Observation } \\
\text { frequency }\end{array}$ & & $\begin{array}{l}\text { Velocity Gron } \\
1961-81 \mathrm{l}\end{array}$ & $\begin{array}{l}\text { th at Annual } \\
1961,65\end{array}$ & $\begin{array}{c}\text { ercentage Ra } \\
1966-70\end{array}$ & $\begin{array}{l}\text { surng } \\
1971-75\end{array}$ & $1976-80$ & 1981 \\
\hline \multirow[t]{6}{*}{ M1 } & 00 & Mean & 325 & 371 & 196 & 364 & 3.39 & 474 \\
\hline & & $\mathrm{SD}$ & 362 & 262 & 302 & 3.64 & 349 & 9.13 \\
\hline & & Gange & $-4.47,1390$ & $-1,18,9,44$ & $-4,06,7.08$ & $-3.36,9.00$ & $-4.16,10.02$ & $-4.48,13.90$ \\
\hline & पQMA & Mean & 3.12 & 3.17 & 236 & 2.94 & 3.77 & 4.35 \\
\hline & & SD & 158 & 179 & 152 & 116 & 1.51 & 1.39 \\
\hline & & Range & $-1,0,698$ & $1,01,586$ & $-09,515$ & $\because 70,5.47$ & $1.86,6.98$ & $2.61,6.01$ \\
\hline \multirow[t]{6}{*}{$\mathrm{M} 2$} & $\mathrm{QQ}$ & Mean & $\$ 17$ & 59 & $\therefore 68$ & $\because 28$ & 81 & 47 \\
\hline & & $\mathrm{so}$ & $4: 05$ & 262 & 354 & 4413 & 487 & 803 \\
\hline & & Bange & $-823 / 1175$ & 432,436 & $-781,575$ & -8236.26 & $-609,1175$ & $-7.00,10.83$ \\
\hline & पQNA & Mean & 04 & -125 & 106 & -65 & 60 & 206 \\
\hline & & $\mathrm{sD} \alpha$ & 236 & 187 & 172 & 241 & 268 & 141 \\
\hline & & Range & $-5,32,631$ & 532229 & $-276,301$ & 446,396 & $=384,631$ & 23,366 \\
\hline
\end{tabular}

year. As was apparent in chart 3 , quarter-tomquater Auctuations can be significant; yet, over the two decades, the standard deviation of its grow thate has remained about 3.00 . While extrapolating the longrum velocity growth rate of $\mathrm{Ml}$ to 1981 underestimates the observed growth ate, the 4.74 percent rate is well within one standard deviation of either the 1976-80 mean or that of the full $1961-81$ period, and represents a fuctuation that is comparatively small in terms of the range of observed grow thates during either the subperiod or the full period as shown in ahare 3 .

For M1, QQ and $4 Q M A$ have roughly the same average growth rates; for $\mathrm{M} 2$, the $4 \mathrm{QMA}$ grow th rate is relatively more volatile that the QQ growth rate. Yet, in absolute tems the difference between $Q Q$ and $4 Q M A$ is about equal for $\mathrm{Ml}$ and $\mathrm{M} 2$ for the entire $1961-81$ period ( -.13 ) and for each subperiod except 1976-80 and 1981. For both M1 and M2, the variability (SD) of $4 Q \mathrm{MA}$ is naturally significantly less than that of $Q Q$. The standard devations of velocity growth computed on a four-quater moving average are about one-half of the quaterly version for Ml and the base and between onewalf and twothirds for M2. Moreover, the standard deviation for 1981 is smaller than for the preceding subperiod. The implication is, as usual, that quarterly monetary statistics are a less useful guide to the longer-rum behavior of money than averages over longer periods.
In summary, whether we look at $\mathrm{M} 1$ or $\mathrm{M} 2$, the information displayed in chat 3 and compiled in table 2 conveys the same message: namely, the behavion of monetary aggregate velocites in 1981 is not qualitatively different than over the preceding 20 yeat period or any of the subperiods. This is clearest when considering the fourquarter moving average growth rates, though the more volatile quarter-to-guater rates tell essentially the same story. While velocity growth rates were higher in 1981 than in preceding subperiods during $1961-81$, there is no evidence that credit use and fnancial innovations have severed the ink between monetary aggregates and the inflation rate.

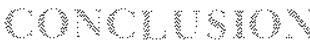

Much of the current debate over U.S. economio policy has focused on the wishom of targeting a monetary argregate to control inflation. Some critics of such policies have alleged that financial innovations have both made money urcontrollable and severed its predictable link with national income and prices. Others have argued that non-monetary assets or liabilities maty have a closer link than money to income over the long run. This article has focused on the predictable linkage issue by examining the principal function of money and credit, the mediation of exchange. Since credit's mediation 
function depends crucially on the predictable source of monetary settlement, there is no theoretical support for assertions that the increasing use of credit has severed money's link to income. In terms of the empirical evidence for the year 1981, both M1 and M2 velocities grew reasonably close to their trend rates. This is grossly inconsistent with assertions that monetary policy is ineffective.

While the controllability issue has not been addressed in this article, an analysis of the changes in monetary aggregates in relation to Federal Open Market Committee (FOMC) directives during 1981 suggests that both $\mathrm{M} 1$ and $\mathrm{M} 2$ movements were strikingly in accord with the intentions of the FOMC. ${ }^{26}$

Consequently, there appears to be no reasonable foundation - theoretical or empirical-for abandoning the use of a monetary aggregate as the vehicle for monetary policy. Unless or until velocity becomes more umpredictable or fuctuates over ranges not previously observed, the usefulness of monetary aggregates in controlling infation and maintaining economic stability will be undiminished.

265ee Dandel L. Thomton, "The FOMC in 1981: Monetary Comtrol in at Changing Finameial Emveronment," this Recieu (April 1982), pp. $3-22$.

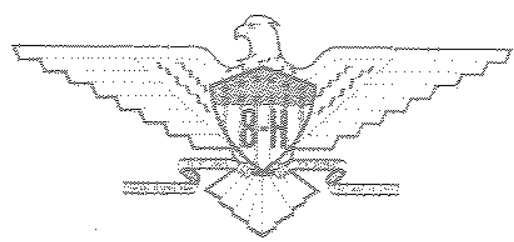

